\title{
Stakeholder Analysis of the Management Model of Intermodal Transportation in The Cirebon Region During Pandemic COVID-19
}

\author{
Herry Hermawan $^{1}$, Pratikso ${ }^{2}$, Rahmat Mudiyono ${ }^{3}$ \\ ${ }^{1}$ Bina Marga Office, West Java, Indonesia, ${ }^{23}$ Civil Engineering Department, Sultan Agung Islamic \\ University, Semarang, Indonesia \\ \{herryhermawan0420@gmail.com¹,pratikso@unissula.ac.id²\}
}

\begin{abstract}
The main problem of transportation in urban areas is that the growth of private vehicles is not proportional to the increase in the length of the existing roads, so this will make policy makers begin to suppress the use of private vehicles and improve public transportation infrastructure. The use of various modes of transportation so that people can move from one type of transportation to another quickly, cheaply, safely, and comfortably, it requires integrated management of existing stakeholders. The research objective is to analyze the policies of the Cirebon City Government in dealing with transportation problems and traffic jams, (2) to find alternative policies that should be taken by the Cirebon City Government in overcoming traffic problems. Qualitative descriptive method was used for this research. The data collection technique used structured interviews and took as many as 6 respondents from related stakeholders, namely the Department of Traffic and Road Transportation of the Transportation Agency, the Police, Members of the Cirebon City DPRD, BAPPEDA staff, and academics from Swadaya Gunungjati University Cirebon. Data analysis used Analytical Hierarchy Process method. The results of this study conclude that (1) the government is still the actor who has the most role in the transportation management model, then the legislature, and the community. This is evidenced by alternative (1) the continued maintenance of Cirebon City Regional Regulation No. 8 of 2016 concerning the implementation of traffic impact analysis because it is still relevant to the development of transportation infrastructure for the city of Cirebon. (2) It is necessary to take measures to improve the road network by the government as well as to develop an integrated public transportation system in the form of a bus rapid transit. This policy is a step to reduce congestion by reducing the use of private vehicles. (3) The action of the DPRD's supervisory role should be more enhanced than the role of legislation and budgeting, while the community plays an important role in increasing participation in obeying traffic signs
\end{abstract}

Keywords: transportation management; COVID-19; Cirebon Region

\section{Introduction}

The national transportation system (sistranas) as a system of transportation that is systematically organized, which consists of road transportation, rail transportation, river or lake transportation, crossing transportation, sea transportation, and air transportation interacting with the support of receivables and transportation software effective and efficient. Sistranas serves to serve the movement of people and / or goods between national nodes or 
cities, and from national nodes or cities to abroad and vice versa [1]. Cirebon city is located at $108^{\circ} 33$ East Longitude and $6^{\circ} 41$ South Latitude on the North coast of Java Island, the eastern part of West Java, extending from west to east $\pm 11 \mathrm{Km}$ with an altitude from sea level $\pm 5 \mathrm{M}$ (including lowlands). Cirebon city can be reached by road as far as $130 \mathrm{~km}$ from the city of Bandung and $258 \mathrm{~km}$ from the city of Jakarta. The city of Cirebon is located in a strategic location and is the hub of transportation movements between West Java and Central Java. Located in the coastal area, Cirebon City has a wider area of land compared to its hilly areas. $[2]$.

Urban transportation plays a vital role in the economic and social development of countries, even though the current transportation systems in many developing countries are still confronted with numerous problems [3]. According to [4], a common problem in big cities in the world including Indonesia, especially in Cirebon City is transportation where the movement of the people is getting higher. The problem is that the growth of private vehicles is not proportional to the increase in the length of existing roads, so this will make policy makers begin to suppress the use of private vehicles and improve public transportation infrastructure. This can be achieved through the intermodal transportation system and the integrated (multimodal) public transportation system. This means that various modes can be combined properly and efficiently and effectively so that people can move from one type of transport to another quickly, cheaply, safely and comfortably.

Transportation is one of the aspects that provide many research and development opportunities, especially in technical aspects such as: (1) Flow Passenger Techniques at transportation nodes (stations, terminals, ports, airports) in the framework of technical engineering to prevent passenger buildup, and (2) Engineering environmentally friendly and inexpensive construction systems, in order to provide affordable transportation node infrastructure development solutions [5]. In March 2020, the Indonesian government recommended prevention and control of public health due to the Covid-19 pandemic by closing schools; cancel large meetings; avoiding travel to public places; promoting and maintaining distance when socializing, not shaking hands, kissing or hugging and other basic protective measures, advising people showing respiratory symptoms to stay at home, isolate themselves, and immediately go to a health care facility [6].

In fact, besides coming with as many negative impacts as it has, actually Covid-19 also has a positive side. At least for us as education personnel, we need to be aware that the Covid-19 emergency seems to make us aware of the demands for change in social life. With the Covid19 pandemic, most people who previously lacked awareness of healthy living became more concerned about the health of themselves and their families. Government policies that often campaign for new habits related to the Covid-19 pandemic, such as maintaining social / physical distancing when doing activities outside the home, frequently washing hands when entering public crowds, in anticipation of the prevention of covid-19 transmission. Another impact due to the Covid-19 pandemic is the disruption of information technology in the economic, social, banking and other aspects that have been widely felt without being contained. In terms of transportation, there is a perception that public transportation is riskier than private transport because it is closer to other people. perhaps, sometimes unavoidably, in vehicles and on public transport stations [7]. The objectives of this research are (1) to analyze the policies of the Cirebon City Government in dealing with transportation problems and traffic jams, (2) to find alternative policies that should be taken by the Cirebon City Government in overcoming traffic problems. 


\section{Method}

This research is a descriptive qualitative research type because it describes the facts or characteristics of a certain population by interpreting and analyzing data in the form of descriptions based on conditions and realities in the field [8]. Researchers carefully investigate an event, activity, process, or group of individuals. Cases are limited by time and activity, and researchers collect complete information using various data collection procedures based on predetermined time [9]. AHP is used in this study to help identify preferred alternatives [10] AHP (Analytic Hierarchy Process) is used as a data processing technique by the author as a more comprehensive data processing technique because it is used to understand complex problems involving many factors. Another consideration is that each selected respondent is an expert resource person or those who have competence in assessing policies in overcoming traffic congestion. The selected respondents included bureaucrats as regulators such as POLRI and DLLAJR (Traffic and Highway Service, Cirebon City Government), BAPPEDA. Apart from that, members of the DPRD, as stakeholders in policy making, from academia, in this case Regional Development and Transportation Observers, as well as the general public, road users in Cirebon City.

\section{Result and Discussion}

This research examines the extent of the influence of a Cirebon City Government policy and the priority of policy selection taken by stakeholders. At the actor level, it is clear that the very central portion of the government is due to its position as an executive institution that carries out policies on the one hand and policy makers, on the other. At this level, the results of the research illustrate that these three actors play an important role in each choice of action taken by each actor. This can be seen from the responses given by the experts which are presented in Figure 1 below:

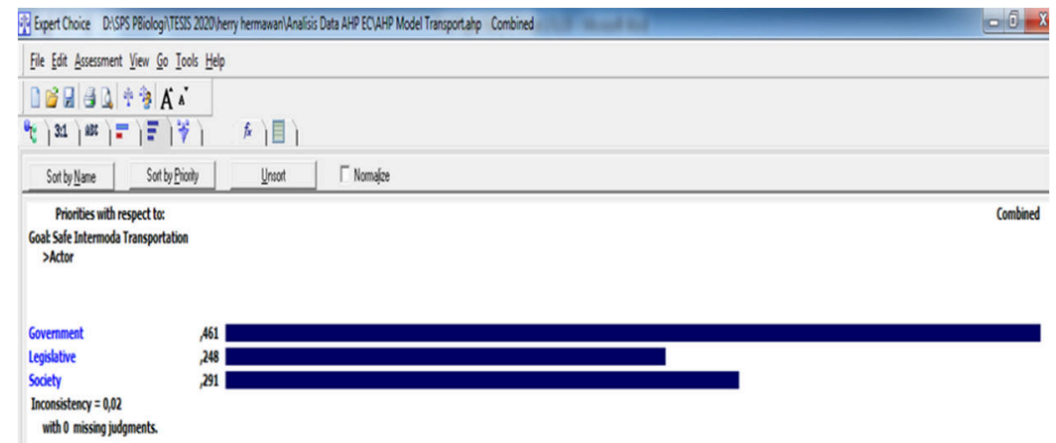

Fig 1. Output Analysis of the Actors

Figure 1 shows the results of the analysis with Expert choice which shows that the first priority based on the results of the interview of respondents is the government at $46.1 \%$, followed by community actors at $29.1 \%$, and legislative actors at $24.8 \%$. The results of the analysis show that the consistency value (Consistency Index) is $0.02 \leq 0.1$, so it can be concluded that the results of the analysis are consistent. Based on the results of the data input 
process presented above, it can be concluded that the actor who is most dominant and has a big role in achieving the goal of creating the ideal transportation conditions as defined is the government actor. According to all 6 respondents, the government is the most important and strategic actor with a weight of $46.1 \%$. Followed by community actors at $29.1 \%$ and legislative actors with a weight of $24.8 \%$. This figure illustrates the strong influence of the government when compared to the role of society and the legislature.

This data also shows community actors $(29.1 \%)$ as the second actor who has an important role in achieving the goal of creating ideal transportation. This is reasonable because society is a factor that is directly affected by the policies implemented by the government. Meanwhile, the legislature is $24.8 \%$ considering that the DPRD legitimizes the regional regulations initiated by both the DPRD and the Government. This output also indicates a weakness in the legislative function, which should be more dominant in policy selection.

Table 1. Map of Stakeholder Respondents

\begin{tabular}{|c|c|c|c|}
\hline Respondent & Occupation & Interest & Obstacles \\
\hline I & $\begin{array}{l}\text { Government } \\
\text { (Transportation } \\
\text { Department) }\end{array}$ & $\begin{array}{l}\text { Regulator, carry out the } \\
\text { government's vision and } \\
\text { mission }\end{array}$ & $\begin{array}{ll}\text { - } & \text { Budget } \\
\text { - } & \text { Coordination }\end{array}$ \\
\hline II & $\begin{array}{l}\text { Government } \\
\text { (PUPR department) }\end{array}$ & $\begin{array}{l}\text { Regulator, carry out the } \\
\text { government's vision and } \\
\text { mission }\end{array}$ & $\begin{array}{ll}\text { - } & \text { Budget } \\
\text { - } & \text { Coordination }\end{array}$ \\
\hline III & Government (Bappeda) & $\begin{array}{l}\text { Regulator, carry out the } \\
\text { government's vision and } \\
\text { mission }\end{array}$ & $\begin{array}{ll}\text { - } & \text { Budget } \\
\text { - } & \text { Coordination }\end{array}$ \\
\hline IV & $\begin{array}{l}\text { Legislative } \\
\text { (DPRD member) }\end{array}$ & $\begin{array}{l}\text { Carry out the functions } \\
\text { of control, legislation, } \\
\text { budgeting }\end{array}$ & $\begin{array}{ll}- & \begin{array}{l}\text { Human } \\
\text { resources }\end{array} \\
\text { - } & \begin{array}{l}\text { Conflict } \\
\text { interest }\end{array}\end{array}$ \\
\hline$\overline{\mathrm{V}}$ & $\begin{array}{l}\text { Police } \\
\text { (law enforcement } \\
\text { officers) }\end{array}$ & $\begin{array}{l}\text { Implement traffic } \\
\text { regulations }\end{array}$ & $\begin{array}{ll}- & \text { Budget } \\
\text { - } & \text { Coordination }\end{array}$ \\
\hline VI & Society & Daily activity & Participatory rules \\
\hline
\end{tabular}

Based on the results of the data input process presented above, it can be concluded that the actor who is most dominant and has a big role in achieving the goal of creating ideal transportation conditions as defined is the government actor. Although government actors are more dominant than legislative and community actors, the magnitude of the role composition will change significantly when a sensitivity analysis and test is carried out. The Legislative Body is a government deliberative body with the power to make laws. The legislature is known by several names, namely parliament, congress, and national assembly. In the Parliamentary system, the legislature is the highest body and refers to the executive. In a presidential system, the legislature is the same branch of government, and is independent, of the executive. In Indonesia, the function of the legislature is very large and very strong in terms of formulating and enforcing a policy. As its function is divided into three, namely: 


\subsection{Legislation Function}

In its legislative function, the commission can propose a draft Regional Regulation and discuss draft regional regulations together with local governments, both on the draft Perda proposed by the Council and the initiative proposed by the Regional Government. If the draft Perda is an initiative proposed by council members, then the tasks that can be carried out are starting from the preparation, drafting, discussion and refinement of the draft Perda, in accordance with the scope of their duties. More detailed provisions related to these duties and authorities are usually set out in the House Rules of Procedure.

To support the drafting and discussion of the Perda, the commission can conduct working visits in order to seek and capture public aspirations related to the substance of the draft Perda to be discussed. In addition, the Commission can also hold work meetings and hearings to enrich material on the Draft Perda being discussed. After that, discussions were held with the local government (related agencies appointed by the Regent / Mayor) to obtain mutual consent.

a. In the budget function, the commission has the following duties:

hold preliminary discussions regarding the preparation of the Draft Regional Revenue and Expenditure Budget which is included in the scope of its duties together with regional governments;

b. hold discussions and submit proposals for improving the Draft APBD.

\subsection{Budgeting Function}

The function is to determine the budget / budget, impose or increase taxes and expenditures and use of money especially the use of the Regional Revenue and Expenditure Budget. The high role and expectations of the community for the legislative body is not accompanied by the optimization of the functions of the three functions inherent in the legislative institution. There is a visible conflict of interest with respect to the background of the legislature. This then becomes one of the obstacles in carrying out the functions which are the main tasks of the legislative body.

\subsection{Oversight function}

a. The supervisory function of DPRD members is to supervise the implementation of Regional Regulations and APBD which fall within the scope of their duties; discuss and follow up on the results of the Bawasda / BPKP / BPK examinations related to the scope of their duties.

b. Supervise local government policies.

Society is (as a translation of the term society) is a group of people who form a semiclosed (or semi-open) system, where most of the interactions are between individuals who are in the group. Generally, the term community is used to refer to a group of people who live together in one regular community. The smaller role of the community which is reflected in the results of expert choice is not the same as the smaller meaning of society as a whole. This can be seen from the results of the sensitivity test. If the community's participation is increased in realizing the objectives of the transportation system, it will show a significant change in the value of the achievement of transportation policy objectives. The role of the community as transportation users will be important when there is a distribution of roles and responsibilities between the three stakeholders. 
Table 2. Results of the Analysis Output on Stakeholder Actions

\begin{tabular}{lccc}
\hline \multicolumn{1}{c}{ Actor's actions } & Alt 1 & Alt II & Alt III \\
\hline Road Network Development & 0,7 & 0.3 & 0.1 \\
Arranging transportation routes & 0,6 & 0.1 & 0.3 \\
Control of goods transportation & - & - & - \\
Controlling & 0.4 & 01 & 0.5 \\
Budgeting & 0.6 & 0.1 & 0.3 \\
Legislation & 0.6 & 0.1 & 0.3 \\
signs and road markings & 0.6 & 0.1 & 0.2 \\
Use of public transportation & 0,6 & 0.1 & 0.3 \\
Increased participation & 0.6 & 0.1 & 0.3 \\
\hline
\end{tabular}

\section{Action Analysis:}

The action in question is an action taken by each actor or actor to achieve the goal. Basically the actions of the actors in achieving the goals of achieving the vision and mission of a transportation system are of various kinds. These types of actions are then grouped into three groups based on the results of interviews and questionnaires. The criteria are selected based on the level of importance, or how much influence an action has on achieving destination. The action groupings taken by stakeholders are:

\subsubsection{Road Network Development}

The development of the road network is a top priority carried out by the Cirebon City Government, from several other alternative efforts based on data on low road growth rates, both on a local and national scale. Seeing the results obtained from this study, based on the results of the expert choice output showed a very high correlation $(70 \%)$ to the creation of the desired transportation climate. The road network itself is a unified road network consisting of a primary network system and a secondary road network system that are interwoven in hierarchical relationships. Meanwhile, the road network system is a unit of road that connects and binds growth centers with areas under the influence of its services in a hierarchical relationship. The primary road network system, which is a road network system with the role of goods and services distribution services for the development of all regions at the national level, by connecting all distribution service nodes in the form of activity centers. From this primary road network system which is then connected to the secondary road network system network. The secondary road network system is a road network system with the role of service distribution of goods and services for people in urban areas. From the results of interviews and a number of studies conducted by the Ministry of Public Works, it is known that road network development is a fairly urgent need that the city government of Cirebon needs to take. This is also reflected in the table of results of the Expert Choice software.

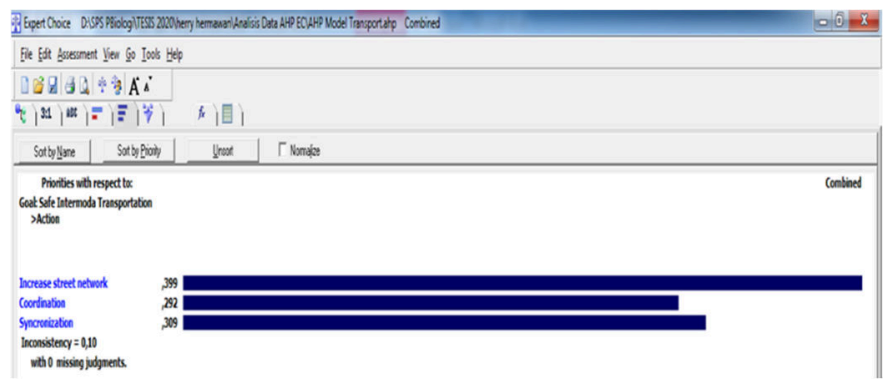

Fig 2. Results of Analysis of Government Policy Actions 
Figure 2 shows the results of the analysis of policy actions taken by the government with the first priority being improving the road network by $39.9 \%$, followed by synchronizing the management of goods transportation with $30.9 \%$, and controlling routes or coordinating passenger transport with $29.2 \%$. Based on the results of the analysis, it is known that the consistency value (Consistency Index) is $0.1 \leq 0.1$ so that the analysis results are consistent. In order to improve the road network in Cirebon City, the city government has encountered quite complex obstacles. The obstacles include land acquisition, high land prices, and the limited budget allocated for land acquisition.

\subsubsection{Route Control}

The number of public transport routes operating in the City area overlaps, causing disruption of the balance of transportation service provision with existing needs and this has an impact on low income levels where in the end the transportation crews operate their vehicles in an orderly and orderly manner in order to achieve more income. Lots. Route control efforts are the next priority (30.9\%) steps that need to be taken by the government to create the desired transportation climate. The number of public transportation operating cannot be controlled by the city government of Cirebon considering that with a route permit that is stipulated or issued, it also comes from the authorization of the Cirebon Regency government.

The condition of the load factor (load factor) is low and the use of public transportation with a small capacity makes public transport services use The cost is relatively more expensive, so the phenomenon that occurs is that many public transport passengers (captive riders) switch to mobility using motorbikes. The reason is that the existing public transport services have not been able to provide certainty of service for transportation service users. Of the various government efforts to reduce the level of congestion in the city of Cirebon, the arrangement of public transport routes, accompanied by enforcement of regulations has been responded as one of the most rational measures to create ideal transportation conditions. Meanwhile, the obstacles the government has encountered with this type of action are the low participation of the community, in this case, workers in the transportation sector and its users.

\subsubsection{Controlling Goods Transportation}

The result of expert choice analysis as in Figure 2 shows that controlling goods transportation (synchronization) is the second priority with $30.9 \%$. Weak supervision and regulation of the operation of goods transportation, both determining the path and parking or loading and unloading of goods vehicles, has resulted in goods transportation activities being one of the main components affecting traffic conditions in the city of Cirebon. Goods transportation that operates beyond capacity as well as special time and route arrangements, worsen transportation services. The concentration of goods transporting vehicles such as Tron toon type trucks, container trucks at certain times causes a very severe congestion.

The disorderly factor in the transportation of goods is due to the weakness of government actors at the time of policy implementation, which is then responded by the public as an end user of transportation, one of the contributors to transportation problems in Cirebon City. The results of the analysis (output) of the legislative function in transportation management in the Cirebon region are presented in Figure 3 below: 


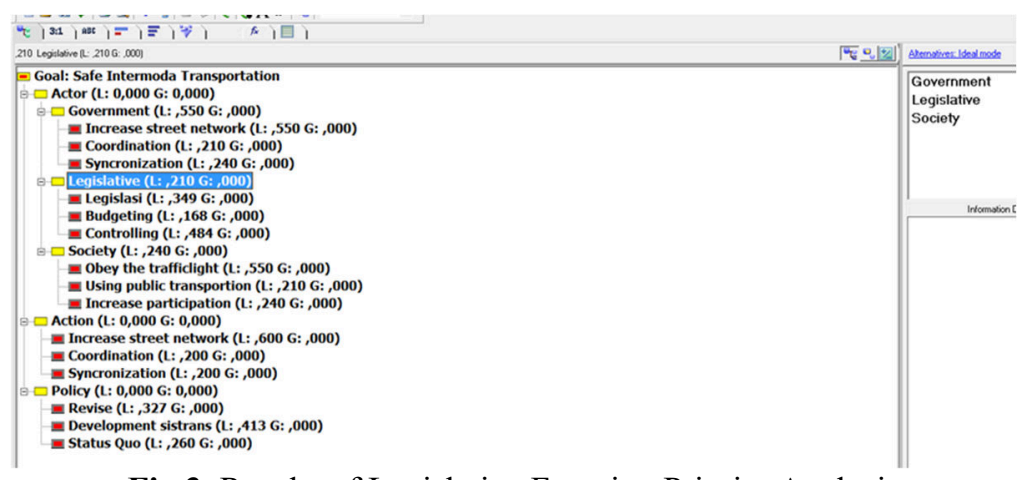

Fig 3. Results of Legislative Function Priority Analysis

Figure 3 shows the priority of the legislative function based on interviews with 6 respondents using expert choice which shows that the supervisory role is $48.4 \%$, followed by the legislative role of $34.9 \%$, and the role of the budget (budgeting) by $16.8 \%$.

\subsubsection{Supervision Function}

The supervisory function inherent in legislative members which is also regulated in the law as it reads, which includes the duties and powers of DPRD, which is to supervise the implementation of regional regulations and other laws and regulations, regional head regulations, APBD, regional government policies, in implementing regional development programs, and international cooperation in the regions. One thing that is the finding of this study is the size of the respondents' expectations of the supervisory function $(48.4 \%)$ of the members of the Cirebon City legislature. As an explanation, it is found that as a member of the legislature, with its political privileges, it is believed to be able to significantly improve the transportation system, if the optimal use of the supervisory function is used.

The supervisory function of the Cirebon City DPRD in this study can be concluded that it has not been implemented properly. In carrying out its supervisory function, the DPRD is expected to really be able to ensure that local governments take sides with the public interest. The government must also be able to realize the common goals and interests that have been agreed upon in the legislation and budgeting process. Based on this, it was then concluded that a supervisory function from community actors was needed who could help the imbalance of the oversight function of the DPRD in the implementation of development. This supervisory function encounters the limitation of legislative members in monitoring policy implementation, given the many problems that need the attention of representatives of the people. The unclear supervisory mechanism is also an obstacle in carrying out this supervisory function.

\subsubsection{Legislation Function}

The basic function of DPRD is actually the legislative function is the most basic function among other tasks. The legislative function as described in the previous section is very influential in the process of formulating and determining a policy product. The results of AHP processing show $34.9 \%$ of its effect on the achievement of the desired transportation conditions, if this function is carried out correctly. However, in carrying out this function, again the main obstacle found is the low level of understanding of legislative members in relation to this very basic function. 


\subsubsection{Budgeting function}

The budgeting function found in this study was the last priority chosen by the respondents, but government officials considered it the most decisive thing. The function of budgeting or budgeting is responded (16.8\%) lower than the function of legislation and supervision, as a factor that can cause the achievement of the objectives of good transportation. In this study, respondents considered that the optimization of the supervisory function and the legislative function inherent in DPRD members played a greater role in realizing ideal transportation conditions as outlined in the regional regulation on transportation. As in Article 41 of Law 32 of 2004 concerning Regional Government, it is stated that DPRD has legislative, budgeting and supervisory functions.

These three functions are normatively and operationally attached directly to the DPRD Leadership and Members. We can see this in the DPRD apparatus, besides the commission, there is also a Budget Agency which functions to carry out tasks in the APBD discussion with the executive budget team. The Budget Agency has the task of continuing the budget discussions that have been carried out by the commission commissions according to their fields and tasks.

Based on the above mechanism the role of the DPRD in relation to preparing and approving regional revenue and expenditure budgets to be used in carrying out development programs, including building or procuring transportation facilities and infrastructure. The constraints identified are constraints on Human Resources. As is known, the pattern of DPRD member recruitment carried out by political parties has many weaknesses, such as unclear criteria and basic competencies for legislative candidates. Most of the political parties nominate candidates with a simple recruitment pattern that is carried out regardless of the capacity and capability of the cadres.

The problem then arises when the capacity of a people's representative is needed to build a system that can bring the people they represent to a better condition. As in the case of the preparation of the APBD, skills and knowledge are very technical in nature, it will appear that some members of the legislature do not understand. This is the reason for the low response from respondents in terms of using the budgeting function.

In this study, it was also found that a DPRD member really needs supporting staff who help carry out their duties and functions. Expert staff in budgeting, for example, are important, because the budget problems of each work unit have the characteristics and techniques of budgeting and implementation requires detailed and technical knowledge. In the budget planning process, the government budget preparation work team basically has a priority for activities or work programs, which are different from what are priorities according to members of the parliament. So that many activities are in terms of planning, and the value of budgeting is not correct, both in terms of allocation or budget size. Here, qualified knowledge is needed to match the ability of bureaucrats whose skills and experience are better informed and mastered the problems.

In the regional financial management cycle, the planning stage is a very crucial stage. The role of the DPRD and the community in this planning stage is very large. The quality of the results (outcomes) from regional financial management is greatly influenced by how well the planning is made. At this planning stage it can be divided into 3 parts, namely, what is the input, process and output. The next priority scale analysis is for community actors as described in Figure 4 below. 


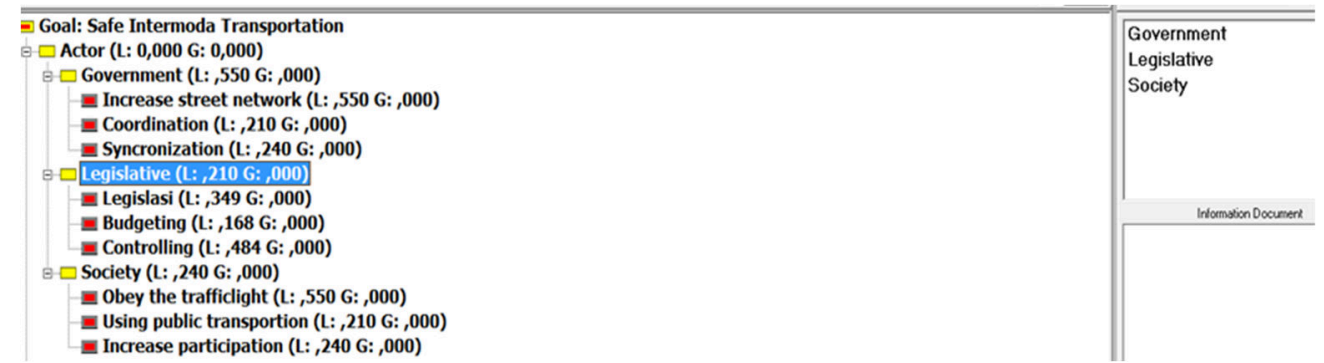

Fig 4. Results of Analysis of Alternative Community Actions

Based on Figure 4 shows that of the 3 alternative actions taken by the community, the first priority is to obey road signs and markings by $55 \%$, followed by an increase in community participation by $24 \%$, and the third priority is to use public transportation by $21 \%$. The explanation of alternative community actions is presented as follows:

a. Obey the signs and markings. From a number of studies conducted by both the National Police and the Ministry of Transportation to evaluate the causal factors of a number of accidents and poor traffic conditions, it was found that the causes originating from human error (human error) are the dominant factor where human error is identical to violations of signs and markers when passing. This study further strengthens the statement above, seeing a very high response to the compliance factor of traffic users with road signs and markings (55\%). In the human factor, there are 2 (two) background aspects in traffic life. First is the intellectual aspect, the second is the personality aspect. Intellectual aspect includes knowledge of signs, markers, traffic rules and skills to drive or drive a vehicle. For the first aspect, this is closely related to a person's intellectual quotient (IQ). Personality aspects include mental attitude to behave on the road, awareness of discipline to comply with rules and commitment to safety. For the second aspect, this is closely related to a person's emotional quotient (EQ).

b. Increasing Public Participation in Planning and Policy Formulation

The results of AHP analysis with Expert choice show that the second priority is an increase in community participation in planning and policy formulation by $29 \%$. As has been explained above, that in planning or formulating a draft regulation, the aspirations of the community are not widely accommodated. This is because the development planning deliberations (musrenbang) are held at the village or sub-district level, both the mechanism and its implementation do not seem to follow the system or mechanism that has been previously agreed upon. So that the outcome of the musrenbang is not as expected. This suboptimal role of the community is one of the weaknesses in planning and formulating regional regulations. Another obstacle is the regional regulation on participatory, which is not known by many community members.

c. Use of Public Transportation

The results of AHP analysis with Expert choice show that the third priority of community actors is the use of public transportation by $21 \%$. The lack of optimism in the use of public transport terminals that have been provided and in some parts of the city has not yet functioned as a transfer point for public transport, so public transport does not yet have a representative travel destination orientation, resulting in the emergence of a shadow terminal which in turn triggers traffic chaos and service uncertainty. public transportation. Based on this fact, respondents see that the use of public transportation is the third priority $(21 \%)$. In addition to improving urban transportation routes in Cirebon 
City, which will also be optimized. This is an effort to curb and reorganize the flow of public transportation.

\subsection{Action Analysis}

The action in question is an action taken by each actor or actor to achieve the goal. Basically the actions of the actors in achieving the goals of achieving the vision and mission of a transportation system are of various kinds. These types of actions are then grouped into three groups based on the results of interviews and questionnaires. The criteria are selected based on the level of importance, or how much influence an action has on achieving destination. The action groupings taken by stakeholders are:

\subsubsection{Road Network Development}

The development of the road network is a top priority carried out by the Cirebon City Government, from several other alternative efforts based on data on low road growth rates, both on a local and national scale. Seeing the results obtained from this study, based on the results of the expert choice output showed a very high correlation $(70 \%)$ to the creation of the desired transportation climate. The road network itself is a unified road network consisting of a primary network system and a secondary road network system that are interwoven in hierarchical relationships. Meanwhile, the road network system is a unit of road that connects and binds growth centers with areas under the influence of its services in a hierarchical relationship.

The primary road network system, which is a road network system with the role of goods and services distribution services for the development of all regions at the national level, by connecting all distribution service nodes in the form of activity centers. From this primary road network system which is then connected to the secondary road network system network. The secondary road network system is a road network system with the role of service distribution of goods and services for people in urban areas. From the results of interviews and a number of studies conducted by the Ministry of Public Works, it is known that road network development is a fairly urgent need that the city government of Cirebon needs to take. This is also reflected in the table of results of the Expert Choice software.

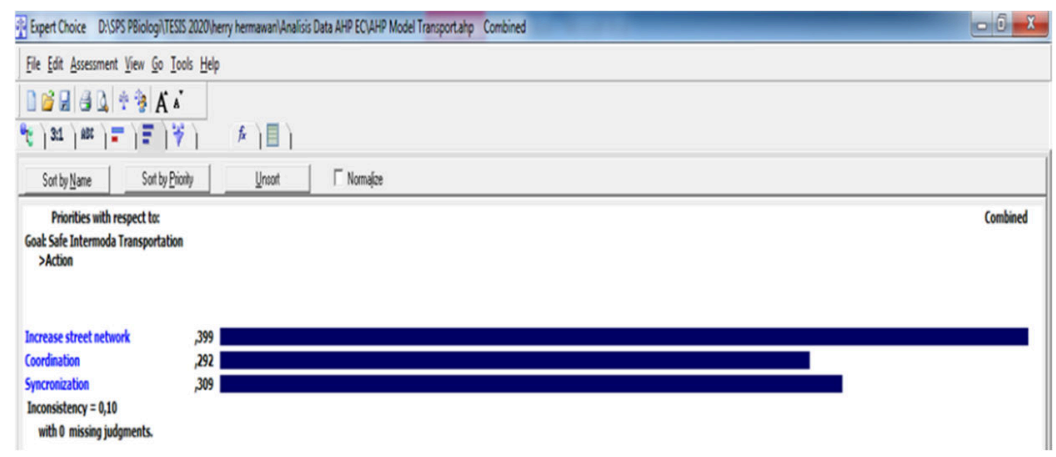

Fig 5. Results of Analysis of Government Policy Actions

Figure 2 shows the results of the analysis of policy actions taken by the government with the first priority being improving the road network by $39.9 \%$, followed by synchronizing the management of goods transportation with $30.9 \%$, and controlling routes or coordinating passenger transport with $29.2 \%$. Based on the results of the analysis, it is known that the 
consistency value (Consistency Index) is $0.1 \leq 0.1$ so that the analysis results are consistent. In order to improve the road network in Cirebon City, the city government has encountered quite complex obstacles. The obstacles include land acquisition, high land prices, and the limited budget allocated for land acquisition.

\subsubsection{Route Control}

The number of public transport routes operating in the City area overlaps, causing disruption of the balance of transportation service provision with existing needs and this has an impact on low income levels where in the end the transportation crews operate their vehicles in an orderly and orderly manner in order to achieve more income. Lots. Route control efforts are the next priority (30.9\%) steps that need to be taken by the government to create the desired transportation climate. The number of public transportation operating cannot be controlled by the city government of Cirebon considering that with a route permit that is stipulated or issued, it also comes from the authorization of the Cirebon Regency government. The condition of the load factor (load factor) is low and the use of public transportation with a small capacity makes public transport services use The cost is relatively more expensive, so the phenomenon that occurs is that many public transport passengers (captive riders) switch to mobility using motorbikes.

The reason is that the existing public transport services have not been able to provide certainty of service for transportation service users. Of the various government efforts to reduce the level of congestion in the city of Cirebon, the arrangement of public transport routes, accompanied by enforcement of regulations has been responded as one of the most rational measures to create ideal transportation conditions. Meanwhile, the obstacles the government has encountered with this type of action are the low participation of the community, in this case, workers in the transportation sector and its users.

\subsubsection{Controlling Goods Transportation}

The result of expert choice analysis as in Figure 2 shows that controlling goods transportation (synchronization) is the second priority with $30.9 \%$. Weak supervision and regulation of the operation of goods transportation, both determining the path and parking or loading and unloading of goods vehicles, has resulted in goods transportation activities being one of the main components affecting traffic conditions in the city of Cirebon. Goods transportation that operates beyond capacity as well as special time and route arrangements, worsen transportation services. The concentration of goods transporting vehicles such as Tron toon type trucks, container trucks at certain times causes a very severe congestion.

The disorderly factor in the transportation of goods is due to the weakness of government actors at the time of policy implementation, which is then responded by the public as an end user of transportation, one of the contributors to transportation problems in Cirebon City. The results of the analysis (output) of the legislative function in transportation management in the Cirebon region are presented in Figure 3 below. Figure 3 shows the priority of the legislative function based on interviews with 6 respondents using expert choice which shows that the supervisory role is $48.4 \%$, followed by the legislative role of $34.9 \%$, and the role of the budget (budgeting) by $16.8 \%$. 


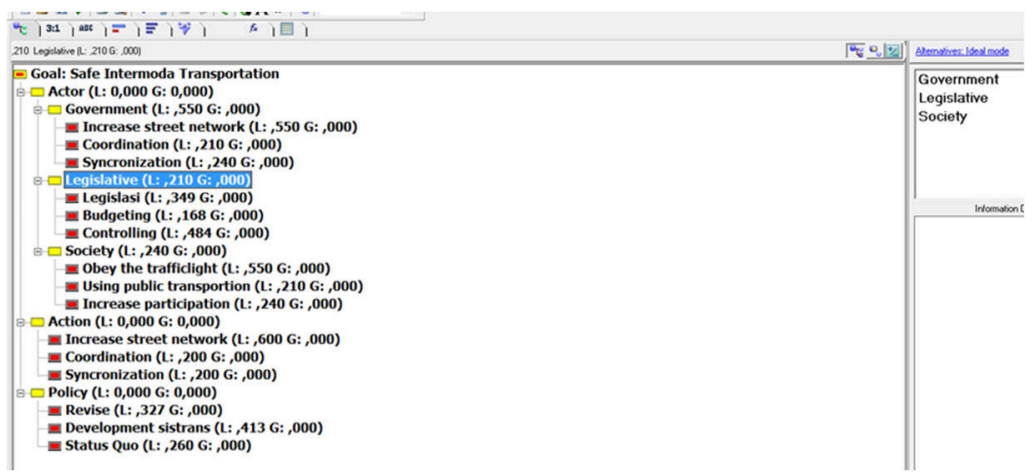

Fig 6. Results of Legislative Function Priority Analysis

\subsubsection{Supervision Function}

The supervisory function inherent in legislative members which is also regulated in the law as it reads, which includes the duties and powers of DPRD, which is to supervise the implementation of regional regulations and other laws and regulations, regional head regulations, APBD, regional government policies, in implementing regional development programs, and international cooperation in the regions. One thing that is the finding of this study is the size of the respondents' expectations of the supervisory function (48.4\%) of the members of the Cirebon City legislature. As an explanation, it is found that as a member of the legislature, with its political privileges, it is believed to be able to significantly improve the transportation system, if the optimal use of the supervisory function is used.

The supervisory function of the Cirebon City DPRD in this study can be concluded that it has not been implemented properly. In carrying out its supervisory function, the DPRD is expected to really be able to ensure that local governments take sides with the public interest. The government must also be able to realize the common goals and interests that have been agreed upon in the legislation and budgeting process.

Based on this, it was then concluded that a supervisory function from community actors was needed who could help the imbalance of the oversight function of the DPRD in the implementation of development. This supervisory function encounters the limitation of legislative members in monitoring policy implementation, given the many problems that need the attention of representatives of the people. The unclear supervisory mechanism is also an obstacle in carrying out this supervisory function.

\subsubsection{Legislation Function}

The basic function of DPRD is actually the legislative function is the most basic function among other tasks. The legislative function as described in the previous section is very influential in the process of formulating and determining a policy product. The results of AHP processing show $34.9 \%$ of its effect on the achievement of the desired transportation conditions, if this function is carried out correctly. However, in carrying out this function, again the main obstacle found is the low level of understanding of legislative members in relation to this very basic function.

\subsubsection{Budgeting function}

The budgeting function found in this study was the last priority chosen by the respondents, but government officials considered it the most decisive thing. The function of budgeting or budgeting is responded (16.8\%) lower than the function of legislation and supervision, as a 
factor that can cause the achievement of the objectives of good transportation. In this study, respondents considered that the optimization of the supervisory function and the legislative function inherent in DPRD members played a greater role in realizing ideal transportation conditions as outlined in the regional regulation on transportation. As in Article 41 of Law 32 of 2004 concerning Regional Government, it is stated that DPRD has legislative, budgeting and supervisory functions. These three functions are normatively and operationally attached directly to the DPRD Leadership and Members. We can see this in the DPRD apparatus, besides the commission, there is also a Budget Agency which functions to carry out tasks in the APBD discussion with the executive budget team. The Budget Agency has the task of continuing the budget discussions that have been carried out by the commission commissions according to their fields and tasks.

Based on the above mechanism the role of the DPRD in relation to preparing and approving regional revenue and expenditure budgets to be used in carrying out development programs, including building or procuring transportation facilities and infrastructure. The constraints identified are constraints on Human Resources. As is known, the pattern of DPRD member recruitment carried out by political parties has many weaknesses, such as unclear criteria and basic competencies for legislative candidates. Most of the political parties nominate candidates with a simple recruitment pattern that is carried out regardless of the capacity and capability of the cadres. The problem then arises when the capacity of a people's representative is needed to build a system that can bring the people they represent to a better condition. As in the case of the preparation of the APBD, skills and knowledge are very technical in nature, it will appear that some members of the legislature do not understand.

This is the reason for the low response from respondents in terms of using the budgeting function. In this study, it was also found that a DPRD member really needs supporting staff who help carry out their duties and functions. Expert staff in budgeting, for example, are important, because the budget problems of each work unit have the characteristics and techniques of budgeting and implementation requires detailed and technical knowledge. In the budget planning process, the government budget preparation work team basically has a priority for activities or work programs, which are different from what are priorities according to members of the parliament. So that many activities are in terms of planning, and the value of budgeting is not correct, both in terms of allocation or budget size. Here, qualified knowledge is needed to match the ability of bureaucrats whose skills and experience are better informed and mastered the problems. In the regional financial management cycle, the planning stage is a very crucial stage. The role of the DPRD and the community in this planning stage is very large. The quality of the results (outcomes) from regional financial management is greatly influenced by how well the planning is made. At this planning stage it can be divided into 3 parts, namely, what is the input, process and output. The next priority scale analysis is for community actors as described in Figure 4 below.

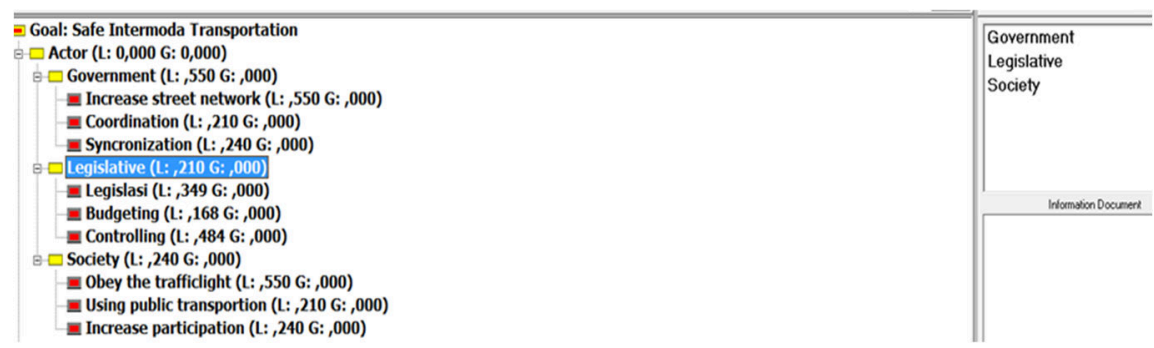

Fig 7. Results of Analysis of Alternative Community Actions 
Based on Figure 4 shows that of the 3 alternative actions taken by the community, the first priority is to obey road signs and markings by $55 \%$, followed by an increase in community participation by $24 \%$, and the third priority is to use public transportation by $21 \%$. The explanation of alternative community actions is presented as follows.

a. Obey the signs and markings

From a number of studies conducted by both the National Police and the Ministry of Transportation to evaluate the causal factors of a number of accidents and poor traffic conditions, it was found that the causes originating from human error (human error) are the dominant factor where human error is identical to violations of signs and markers when passing. This study further strengthens the statement above, seeing a very high response to the compliance factor of traffic users with road signs and markings $(55 \%)$. In the human factor, there are 2 (two) background aspects in traffic life. First is the intellectual aspect, the second is the personality aspect. Intellectual aspect includes knowledge of signs, markers, traffic rules and skills to drive or drive a vehicle. For the first aspect, this is closely related to a person's intellectual quotient (IQ). Personality aspects include mental attitude to behave on the road, awareness of discipline to comply with rules and commitment to safety. For the second aspect, this is closely related to a person's emotional quotient (EQ).

b. Increasing Public Participation in Planning and Policy Formulation

The results of AHP analysis with Expert choice show that the second priority is an increase in community participation in planning and policy formulation by $29 \%$. As has been explained above, that in planning or formulating a draft regulation, the aspirations of the community are not widely accommodated. This is because the development planning deliberations (musrenbang) are held at the village or sub-district level, both the mechanism and its implementation do not seem to follow the system or mechanism that has been previously agreed upon. So that the outcome of the musrenbang is not as expected. This suboptimal role of the community is one of the weaknesses in planning and formulating regional regulations. Another obstacle is the regional regulation on participatory, which is not known by many community members.

c. Use of Public Transportation

The results of AHP analysis with Expert choice show that the third priority of community actors is the use of public transportation by $21 \%$. The lack of optimism in the use of public transport terminals that have been provided and in some parts of the city has not yet functioned as a transfer point for public transport, so public transport does not yet have a representative travel destination orientation, resulting in the emergence of a shadow terminal which in turn triggers traffic chaos and service uncertainty. public transportation.

Based on this fact, respondents see that the use of public transportation is the third priority (21\%). In addition to improving urban transportation routes in Cirebon City, which will also be optimized. This is an effort to curb and reorganize the flow of public transportation. This optimization is carried out on a number of infrastructures such as the use of terminals as the node of city transport traffic flow. Another alternative is the use of pedestrian bridges, zebra crossings and other traffic infrastructure. This action is intended to create a conducive situation for public transport, which in the end, it is hoped that the transfer of private vehicle users will shift to using public transportation. 


\subsection{Analysis of Policy Alternatives}

The results of data analysis regarding the transportation management model in the Cirebon area based on the results of interviews with respondents are presented in the following figure.

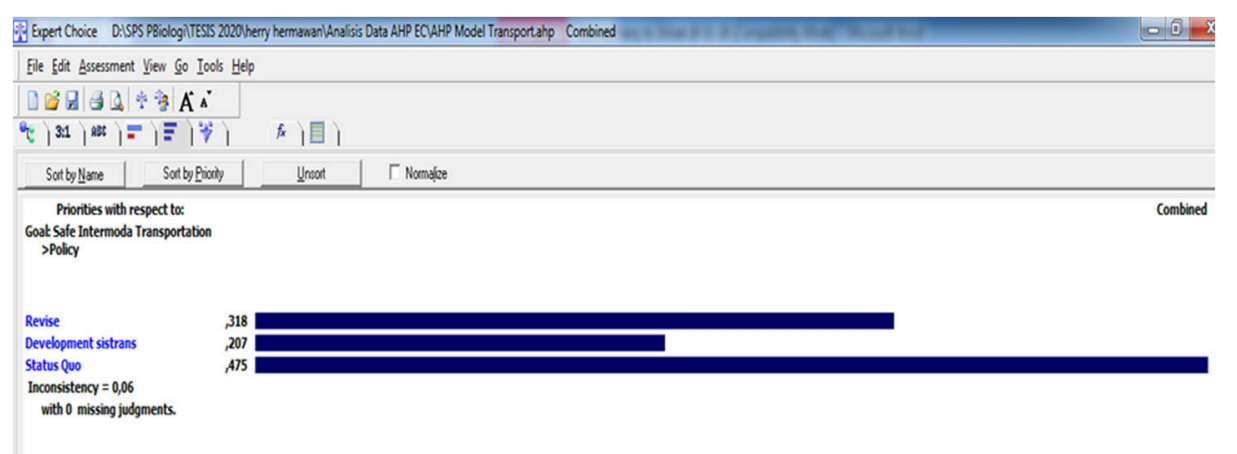

Fig 8. Results of Analysis of Transportation Policy in the Cirebon Region

Figure 5 shows the results of the analysis of transportation policy in the Cirebon region based on interviews with respondents showing that the first priority is the status quo of $47.5 \%$, followed by a revision of policies (Regional Regulations) of $31.8 \%$, and the third priority is the development of a mass transportation system of $31.8 \% .20 .7 \%$. Based on the results of the analysis, it is known that the consistency value (Consistency Index) is $0.06 \leq 0.1$ so that the analysis results are consistent. The discussion is presented as follows:

a. Perda No. 8/2016 (Status Quo)

Cirebon City Regional Regulation No. 8 of 2012 concerning the implementation of road transport traffic impact analysis is an implementation of Law No. 14 of 1992, which is actually a law whose implementation is not in accordance with the development of the current socio-political paradigm. Based on the findings of this study and the results of expert voice data processing, the priority for policy selection on transportation problems, the response is so low that the local government should immediately follow up by establishing a policy in the form of a regional regulation, to avoid developing a counterproductive situation that actually worsens the transportation climate in the city of Cirebon.

b. New Policy / Revision of Land Transportation Regional Regulation

The results of AHP analysis with expert choice show that the second priority is the revision of the Land Transportation Regional Regulation by 31.8\%. Respondents' views on the role of actors, the effect of the actions taken, as well as the obstacles faced by each actor in achieving goals, as well as an analysis of the existing policy alternatives, will then describe alternative policy revisions that can be carried out in overcoming these constraints. In determining the best alternative, researchers conducted an initial study of urban transportation and strategies that could be carried out to achieve and implement the transportation vision and mission of the Cirebon City government. The Analytical Hierarchy Process (AHP) can be used as a tool in determining the priority of land transportation (intermodal) policies in the Cirebon region. This can be done with the presence of quantitative data obtained so that a hierarchy of criteria and alternatives can be arranged, as well as the level of consistency between hierarchies. Validity testing is determined from alternative recommendations that are set and obtained from weighting 
between criteria which shows the role of the assessor in understanding the concept of the Analytical Hierarchy Process is very influential [11].

c. Development of the Mass Transportation System

Policy for developing an integrated public transportation system in the form of a bus rapid transit. Referring to the trial project of the bus rapid transit system operated by the Bandung City Government, as well as the results of data processing carried out in this study, it shows that $20.7 \%$ of mass transportation development policies can lead to improved transportation conditions in Cirebon City. However, this requires structuring and refinement by referring to the way similar strategies are applied in several regions. The bus lane system should be more effective, considering that there have been several similar cases where its success can be emulated. This policy is a step to anticipate congestion that can reduce the use of private vehicles, if it goes according to the concept. However, in the development of this mass transportation system, it is not without flaw, because on the one hand there can be success in mass transit missions, but it does not succeed in reducing congestion, because BRT users are not users of private vehicles but users of other modes of transportation which are only a transfer of transportation modes.

Such success does not affect overall transport conditions. The number of public transport users has decreased the percentage by $1 \%$ per year. This is due to the increasing number of private vehicles, both motorbikes and cars, when in fact urban public transportation should be a very important public policy instrument. In Law No. 22 of 2009 [12] concerning Road Transportation Traffic (LLAJ), especially Article 158, it is stated that the government guarantees the availability of road-based mass transportation to meet the needs of people with public motorized vehicles in urban areas. The plan to develop mass transportation modes by the Cirebon City Government is expected to be able to reduce transportation problems.

\section{Conclusion}

The alternative policies that should be taken by the Cirebon City Government in overcoming traffic problems in the Cirebon area are as follows: (1) the Cirebon City Regional Regulation No.8 of 2016 on the implementation of traffic impact analysis is still relevant because it is still relevant to the development of transportation infrastructure for the city of Cirebon. However, because there are still problems arising from the unsynchronized regulations set by the central government. (2) It is necessary to take measures to improve the road network by the government as well as to develop an integrated public transportation system in the form of a bus rapid transit. This policy is a step to reduce congestion by reducing the use of private vehicles. (3) The action of the DPRD's supervisory role should be more enhanced than the role of legislation and budgeting, while the community plays an important role in increasing participation in obeying traffic signs. The large number of overlapping routes causes a decrease in the comfort level of using public transportation due to congestion, as well as an increase in service uncertainty for transportation users. This is because route permits are also issued by the Cirebon district government, and Cirebon City and its surroundings, making it difficult for coordination between local governments and between agencies. 


\section{References}

[1] Y. Gusleni, "Keterpaduan Pelayanan Angkutan Umum Di Kota Cirebon,” J. Transp. Multimoda, vol. 14, no. 4, pp. 193-206, 2016.

[2] "Geograpich and Climate." Kota Cirebon Dalam Angka. Cirebon : Badan Pusat Statistik

[3] O. Elmansouri, A. Almhroog, and I. Badi, "Urban transportation in Libya: An overview," Transp. Res. Interdiscip. Perspect., vol. 8, p. 100161, 2020, doi: 10.1016/j.trip.2020.100161.

[4] M. Kadarisman, A. Gunawan, and I. Ismiyati, "Implementasi Kebijakan Sistem Transportasi Darat Dan Dampaknya Terhadap Kesejahteraan Sosial Di Jakarta,” J. Manaj. Transp. Dan Logistik, vol. 2, no. 1, p. 59, 2017, doi: 10.25292/j.mtl.v2i1.129.

[5] P. Publik, D. I. Sektor, and P. Darat, "Kementerian perhubungan," vol. 1, no. 8, p. 3811308, 2020.

[6] M. D. Arifin, "Impacts of Coronavirus COVID-19 on the Global Shipping and Maritime Industry in Indonesia and How to Overcome the Coronavirus Outbreak Based on WHO and IMO Recommendations," pp. 1-22, 2020, doi: 10.31219/osf.io/crgv3.

[7] A. Tirachini and O. Cats, "COVID-19 and public transportation: Current assessment, prospects, and research needs," J. Public Transp., vol. 22, no. 1, pp. 1-34, 2020, doi: 10.5038/2375-0901.22.1.1.

[8] Sugiyono, (2017). Metode Penelitian Pendidikan, Kuantitatif, Kualitatif, R \& D. Bandung : Alfabeta.

[9] Creswell, J.W., (2016). Research Design Pendekatan Metode Kualitatif, Kuantitatif, dan Campuran (terjemahan A Fawaid dan Rianayati). Yogyakarta : Pustaka Pelajar.

[10] A. Khaira and R. K. Dwivedi, "A State of the Art Review of Analytical Hierarchy Process," Mater. Today Proc., vol. 5, no. 2, pp. 4029-4035, 2018, doi: 10.1016/j.matpr.2017.11.663.

[11] Firdasari., Iqbal. (2019). Penerapan Metode Analytical Hierarchy Process Dalam Penentuan Prioritas Penanganan Jalan. Jurnal Teknik Sipil Unaya, Vol. 6, No.1, 1-13 http://jurnal.abulyatama.ac.id/tekniksipilunaya

[12] Presiden republik Indonesia, "UU no.22 tahun 2009.pdf." 2009. 